\title{
Nutrition Education in Portuguese Medical Students: Impact on the Attitudes and Knowledge
}

\author{
Ensino de Nutrição nos Estudantes de Medicina: \\ Impacto nas Atitudes e Conhecimentos
}

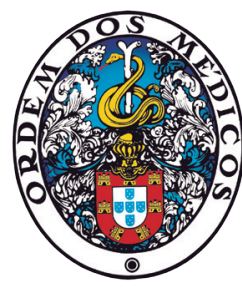

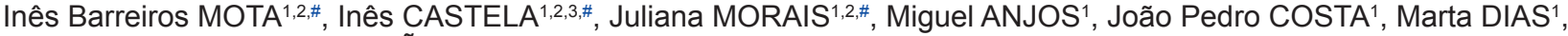 \\ Ana FERNANDES ${ }^{1}$, lara LEITÃO ${ }^{1}$, Urmilk MOHANLAL ${ }^{1}$, Elisa CAMPOS ${ }^{1}$, Maria João CASCAIS ${ }^{1}$, Ana FARIA CA, $^{1,2,}$ \\ Cláudia MARQUES ${ }^{1,2}$, Rita PATARRÃO ${ }^{1}$, Diogo PESTANA ${ }^{1,2}$, Diana TEIXEIRA ${ }^{1,2,4}$, Jaime Cunha BRANCO ${ }^{4,5,6}$, \\ Conceição CALHAU $\mathbb{B}^{1,2}$ \\ Acta Med Port 2020 Apr;33(4):246-251 - https://doi.org/10.20344/amp.11817
}

ABSTRACT

Introduction: Nutrition has been underrepresented in the curriculum of many medical schools and therefore physicians do not feel adequately prepared to provide dietary counselling. The aim of the present study is to determine the impact of a Nutrition and Metabolism curricular unit on nutrition attitudes, knowledge and confidence on future clinical practice of medical students.

Material and Methods: All the students enrolled in the curricular unit (2017/2018) were invited to complete a questionnaire assessing their nutritional knowledge and eating habits at the beginning and at the end of the semester $(n=310)$.

Results: Initially, students reported good eating habits and nutrition knowledge. These aspects improved at the end of the study. Moreover, students reported that they felt more confident to do dietary counselling after intervention.

Discussion: Most medical students answered affirmatively to all questions related with good habits or eating behaviours, and the acquisition of knowledge had an impact in specific attitudes. After the Nutrition and Metabolism classes the students felt able to provide dietary counselling in different clinical settings, but none of the students felt extremely confident about their competencies for dietary counselling. This can be due to the fact that the students involved were in the first year of the integrated master's degree in medicine, which is a preclinical year, and thus distant from the medical reality and from contact with patients.

Conclusion: Nutrition education can have a positive impact on attitudes and eating behaviours, knowledge and in the perception of competencies for dietary counselling.

Keywords: Curriculum; Education, Medical, Undergraduate; Nutritional Sciences/education; Portugal; Students, Medical

\section{RESUMO}

Introdução: A nutrição não tem sido uma prioridade no programa curricular de muitas escolas médicas e, portanto, os médicos não se sentem devidamente preparados para realizar aconselhamento alimentar. O objetivo deste estudo consiste em determinar o impacto do ensino de Nutrição e Metabolismo nas atitudes e comportamentos, conhecimento e confiança na prática clínica futura dos alunos de medicina.

Material e Métodos: Todos os estudantes $(n=310)$ inscritos na unidade curricular $(2017 / 2018)$ foram convidados a preencher um questionário, no início e no final do semestre, para avaliar os seus hábitos e conhecimentos alimentares.

Resultados: Inicialmente, os estudantes apresentavam bons hábitos alimentares e um bom conhecimento nutricional. Não obstante, no final do estudo verificou-se que estes parâmetros melhoraram. Mais ainda, após a unidade curricular os estudantes sentiam-se mais confiantes para realizar aconselhamento nutricional.

Discussão: Após a unidade curricular, a maioria dos estudantes respondeu afirmativamente às questões referentes a atitudes e comportamentos alimentares, sendo que a aquisição de novos conhecimentos pode ser responsável pelo aumento significativo de respostas afirmativas a determinadas questões. Os estudantes sentiram-se capazes de realizar aconselhamento alimentar em diferentes contextos clínicos, mas foram poucos os que reportaram sentir-se fortemente confiantes. Tal pode dever-se ao facto de frequentarem o primeiro ano do mestrado integrado em medicina, ano pré-clínico, sem contacto com a prática médica e com o doente. Conclusão: Pode verificar-se que o ensino de Nutrição numa escola médica teve impacto positivo nas atitudes e comportamentos alimentares, conhecimento e perceção de competências para a realização de aconselhamento nutricional.

Palavras-chave: Ciências da Nutrição/educação; Currículo; Educação de Graduação em Medicina; Estudantes de Medicina; Portugal

\section{INTRODUCTION}

According to the World Health Organization (WHO), $80 \%$ of chronic non-communicable diseases are attributable to modifiable factors such as diet and lifestyle. ${ }^{1}$ Inadequate eating habits $(15.8 \%)$, high blood pressure $(13.0 \%)$ and high body mass index (11.5\%) are the major risks fac- tors of increased disability-adjusted life-years by the Portuguese population. ${ }^{2}$ So it is important that the physician be able to act at this level. ${ }^{1}$

The acknowledgement of the key role of lifestyle in the development of chronic disease and the relationship

\footnotetext{
\# Estes autores contribuíram de forma equitativa para o estudo.

1. Nutrition and Metabolism. NOVA Medical School | Faculdade de Ciências Médicas. Universidade NOVA de Lisboa. Lisboa. Portugal.

2. Center for Health Technology and Services Research. Porto. Portugal.

3. Escola Superior de Saúde. Universidade do Algarve. Faro. Portugal.

4. Comprehensive Health Research Centre. Universidade NOVA de Lisboa. Lisboa. Portugal.

5. Unidade de Epidemiologia de Doenças Crónicas. NOVA Medical School | Faculdade de Ciências Médicas. Universidade NOVA de Lisboa. Lisboa. Portugal.

6. Serviço de Reumatologia. Hospital Egas Moniz. Centro Hospitalar de Lisboa Ocidental. Lisboa. Portugal.

$\triangle$ Autor correspondente: Conceição Calhau. ccalhau@nms.unl.pt

Recebido: 25 de janeiro de 2019 - Aceite: 06 de novembro de 2019 | Copyright @ Ordem dos Médicos 2020
} 
between nutrition and health status is universal. ${ }^{1,3}$ Medical students are prone to make decisions only based on pharmaceutical evidence, and rarely based on data about the impact of nutrition or exercise habits. ${ }^{4}$ The knowledge based on evidence and the acquisition of competencies in nutrition is crucial for physicians, contributing to the optimization of preventive or therapeutic actions, and the reduction of global health costs. ${ }^{5,6}$ However, only less than half of primary care physicians routinely provide dietary counselling. ${ }^{7,8}$ Since medical education is the basis for the future physicians' practice and nutrition is not present in the curriculum of many medical schools, ${ }^{5}$ physicians do not feel comfortable, confident or adequately prepared to provide dietary counselling, which may be related to suboptimal knowledge of basic nutrition science facts and understanding of potential nutrition interventions. ${ }^{5}$

As the physician is commonly the primary health professional in contact with individuals to find solutions to detected health problems, with an active role not only in the treatment but also in the prevention of the disease, it is imperative that these professionals are able to act or refer patients to appropriate health professionals and nutritionists, when necessary. ${ }^{1,5,7,9,10}$

The time devoted to teaching nutrition in the classical curriculum of medical education used to be scarce or inexistent, ${ }^{1}$ which led to its reformulation. The Academy of Medical Royal Colleges in the United Kingdom suggested that medical students should know about nutrition in normal growth and health, public health aspects of nutrition and their relationship with diseases in the early stages of training. ${ }^{11}$ Other studies confirm that nutrition education increases knowledge and confidence in dietary counselling both in medical students and in residents. ${ }^{7,12}$ With these factors considered, the need for physician's nutrition education has never been more urgent and it is imperious that medical schools include nutrition in their curriculum. ${ }^{13}$

In Portugal, the integrated master's degree in medicine (IMM) of NOVA Medical School | Faculdade de Ciências Médicas, NOVA University, was a pioneer in contemplating nutrition as a required curricular unit (CU) in the first year of the medical curriculum, in a total of 75 hours during one semester, according to the recommendation of the Academy of Medical Royal Colleges and the minimum of 25 hours recommended by the National Academy of Sciences. ${ }^{11,14}$

Consequently, at this stage of reformulation of medical education, it is relevant to evaluate the impact of nutritional knowledge acquired in the $\mathrm{CU}$ of Nutrition and Metabolism (NM) about students' attitudes and behaviours, knowledge and importance of nutrition, as well as the perception of dietary counselling skills.

Therefore, the aims of this study were to determine the impact of NM as a required $\mathrm{CU}$ in the first year of the medical curriculum on nutrition attitudes and behaviours, knowledge, confidence on future practice and to evaluate the adherence to the pattern of the Mediterranean diet (MD) of first-year medicine students.

\section{MATERIAL AND METHODS \\ Study design and population}

This is an observational and longitudinal study. All the students enrolled in the CU of NM were invited to participate in the study $(n=310)$. The recruitment occurred in the first week of practical classes. The questionnaire was applied in two moments, at the beginning (March, 2018) and at the end (May, 2018) of the second semester. The contents of the CU of NM which are specified in Table 1, include a minimum contact time of 75 hours. The curriculum was designed by faculty including dietitians, and the classes are also taught by these professionals. Practical classes are characterized by adopting the problem-based learning method, the presentation of clinical cases and discussion of scientific evidence, which is also decisive in the acquisition of knowledge by students.

\section{Instrument}

The questionnaire, developed based on those previously used in similar studies, ${ }^{1,7,15}$ was coded, self-administered on paper with 40 closed questions, and was divided into five sections: socio-demographic data, food attitudes and behaviours, knowledge and importance about nutrition, perception of competencies for dietary counselling and Mediterranean diet adherence (using the PREDIMED score). ${ }^{15}$

The food attitudes and behaviours section contains seven questions concerning healthy eating behaviours, such as "Do you start your meal with soup?" or about self-perception on healthy attitudes, like "Do you know how to correctly interpret nutritional labels?".

The third section, nutritional knowledge and its importance, comprises seven statements that have to be identified as true or false in order to evaluate general nutritional knowledge, such as "The eating habits of a pregnant woman have no impact on the adult life of her child" and also more specific knowledge addressed in the medical students curriculum, for example "Food sources of unsaturated fatty acids are the primary responsible for raising the serum cholesterol level".

The fourth section, perception of competencies for dietary counselling, included three statements regarding the capacity to do dietary counselling to prevent illness, specifically counselling during the first year of life or for obesity.

Table 1 - Contents approached in NM classes

\section{Contents of NM classes}

Global perspective on food and human nutrition

Digestion, absorption, transport, and excretion of nutrients

Macronutrients, micronutrients and xenobiotic metabolism

Regulation of food intake: appetite, hunger and satiety

Dietary reference standards

Food and nutrition-related diseases

Dietary management of chronic diseases

Food-drugs interactions

Research methodologies, scientific literature and information resources 
In addition, this section inquired about the students' confidence to do the dietary counselling in specific diseases with nutritional issues: high blood lipids, kidney failure, bowel cancer, type 2 diabetes and celiac disease. The confidence was demonstrated by the 5-point Likert scale (1 - strongly disagree, 5 - strongly agree).

PREDIMED is a 14-item Mediterranean dietary assessment tool that has been previously validated, it was applied to ascertain medical students' adherence to the MD pattern. ${ }^{15}$ The MD pattern is characterized by a higher consumption of whole or minimally processed foods (fruits and vegetables, pulses, whole grains, dietary fibre, fish, vegetable protein and olive oil) to the detriment of other adverse dietary factors (fast food, sugary drinks, refined grain products, partially hydrogenated or trans-fat). For this reason, the MD is recognized as a healthy pattern, and studies show that is inversely associated with risk of obesity or weight gain. ${ }^{15}$ The response to each of the 14 items is scored with 1 if according with the defined criteria ( 0 - 14 points). ${ }^{15} \mathrm{~A}$ final score $\leq 5$ was considered as "low adherence" to the MD, $6-9$ as a "moderate adherence" and if the final score was $\geq$ 10 "high adherence". ${ }^{15}$

\section{Statistical methods}

Statistical analyses were carried out using IBM SPSS Statistics version 25.0. The participants with missing data from follow-up were excluded and all data entries were double-checked for errors. Descriptive statistics are presented as percentages and median for categorical variables, as the mean and standard deviation (SD) for continuous variables. When testing hypotheses about continuous variables, nonparametric tests (Mann-Whitney, Wilcoxon, qui-square and Fisher tests) were used as appropriate, considering the normal distribution and the number of groups compared. The statistical significance level was set at $5 \%$ and differences were considered statistically significant when $p<0.05$.

\section{Ethics}

This study was approved by the Ethics Committee of NOVA Medical School | Faculdade de Ciências Médicas, Universidade NOVA de Lisboa. The signed written consent and the information to participant were delivered to all participants.

\section{RESULTS}

At the end of the semester, $73 \%$ of the students $(n=$ 225 ) completed the study, with mean age of 19 years, $75 \%$ girls and $94 \%$ of these students were in the first year of IMM without having previously attended another health sciences degree.

\section{Food attitudes and behaviours}

At baseline, the proportion of students that answered affirmatively to most of the questions related with good habits or eating behaviours was $50 \%$ or more than $50 \%$. The question "Do you eat 5 portions of fruit/vegetables daily?" was the exception, to which only $37.1 \%$ replied positively. However, after the classes this figure tended to increase, but was not statistically significant.

In general, the results show that the knowledge acquired in the classes of NM had an impact in the attitudes and eating behaviours of the students after the NM classes (Table 2). The proportion of affirmative answers increased with statistical significance to the questions: "Do you know how to correctly interpret nutritional labels?"; "Do you know how to make healthy food choices? "; "Do you think you are able to control what you eat?"; and "Do you avoid eating foods with high content of fat and/or sugar?".

The increase in the proportion of affirmative answers to the second and last question was the highest, 33\% and $26 \%$ respectively, when comparing the end of the semester with the beginning.

\section{Nutrition knowledge and its importance}

Medical students have a good baseline nutrition knowledge, which is evident in the fact that for each question at least $50 \%$ of the students gave the right answer (Table 3 ). After curricular unit frequency, the proportion of right answers increased significantly only to the first, second and fourth questions.

\section{Perception of competencies for dietary counselling}

According to a 5-point Likert scale, before NM classes, $34.3 \%$ of the students felt able to provide dietary counselling as a preventive measure of disease. Furthermore, more than $50 \%$ of the students mentioned they did not feel able to give dietary counselling to children up to age 1 neither

Table 2 - Percentage of the answers (yes or no) in "Attitudes and eating behaviours" $(n=225)$

\begin{tabular}{|c|c|c|c|c|c|}
\hline & \multicolumn{2}{|c|}{ Before NM } & \multicolumn{2}{|c|}{ After NM } & \multirow{2}{*}{$p$ value $^{a}$} \\
\hline & Yes (\%) & No $(\%)$ & Yes (\%) & No $(\%)$ & \\
\hline Do you cook your own meals? & 54.9 & 45.1 & 56.9 & 43.1 & 0.761 \\
\hline Do you know how to correctly interpret nutritional labels? & 50.7 & 49.3 & 83.8 & 16.2 & $<0.001^{* *}$ \\
\hline Do you know how to make healthy food choices? & 79.0 & 21.0 & 96.0 & 4.0 & $<0.001^{* *}$ \\
\hline Do you think you are able to control what you eat? & 66.5 & 33.5 & 77.6 & 22.4 & $0.009^{*}$ \\
\hline Do you eat five portions of fruit/vegetables daily? & 37.1 & 62.9 & 43.5 & 56.5 & 0.089 \\
\hline Do you start your meal with soup? & 60.4 & 39.6 & 62.8 & 37.2 & 0.935 \\
\hline Do you avoid eating foods with high content of fat and/or sugar? & 54.3 & 45.7 & 80.0 & 20.0 & $<0.001^{* *}$ \\
\hline
\end{tabular}

a: Qui square test

$*: p<0.05$, before versus after; **: $p<0.001$, before versus after 
Table 3 - Percentage of correct answers in the "Knowledge and importance about nutrition" section before and after NM $(n=225)^{7}$

\begin{tabular}{|c|c|c|c|}
\hline & $\begin{array}{c}\text { Before NM } \\
(\%)\end{array}$ & $\begin{array}{l}\text { After NM } \\
(\%)\end{array}$ & $p$ value $^{a}$ \\
\hline An individual with a body mass index (BMI) of $28 \mathrm{~kg} / \mathrm{m}^{2}$ is considered normoponderal. & 75.4 & 92.8 & $<0.001^{* *}$ \\
\hline $\begin{array}{l}\text { Food sources of unsaturated fatty acids are the primary responsible cause for raising the } \\
\text { serum cholesterol level. }\end{array}$ & 48.5 & 76.8 & $<0.001^{* *}$ \\
\hline The eating habits of a pregnant woman have no impact on the adult life of her child. & 98.7 & 98.2 & 0.668 \\
\hline A gram of protein has nine kilocalories. & 50.0 & 66.2 & $0.001^{* *}$ \\
\hline The eating habits have a leading role in the treatment of gastric ulcers. & 98.6 & 98.7 & 0.554 \\
\hline The Portuguese eating habits do not influence the National Health System. & 99.1 & 98.2 & 0.603 \\
\hline Obesity is associated with the development of hypertension. & 97.3 & 99.6 & 0.184 \\
\hline
\end{tabular}

a: Qui square or Fisher test

$* *: p<0.001$, before versus after

Table 4 - Percentage of answers to each point of the Likert scale before and after NM $(n=225)^{1}$

\begin{tabular}{|c|c|c|c|c|c|c|c|c|c|c|}
\hline \multirow[b]{2}{*}{1} & \multicolumn{3}{|c|}{$\begin{array}{l}\text { Before NM } \\
(\%)\end{array}$} & \multirow[b]{2}{*}{5} & & \multicolumn{5}{|c|}{$\begin{array}{l}\text { After NM } \\
(\%)\end{array}$} \\
\hline & 2 & 3 & 4 & & & 1 & 2 & 3 & 4 & 5 \\
\hline 11.6 & 40.9 & 13.3 & 31.6 & 2.7 & $\begin{array}{l}\text { I feel able to do dietary counselling as a preventive } \\
\text { measure of the disease. }\end{array}$ & 0.0 & 9.8 & 12.0 & 73.3 & 4.9 \\
\hline 50.7 & 38.2 & 7.1 & 3.1 & 0.9 & $\begin{array}{l}\text { I have the necessary knowledge to provide dietary } \\
\text { guidance in children up to } 1 \text { year old. }\end{array}$ & 11.2 & 49.6 & 23.2 & 15.2 & 0.9 \\
\hline 17.9 & 44.4 & 15.7 & 21.1 & 0.9 & $\begin{array}{l}\text { I feel confident to give dietary counselling in the } \\
\text { treatment of obesity. }\end{array}$ & 0.4 & 12.1 & 12.5 & 68.3 & 6.7 \\
\hline \multicolumn{11}{|c|}{ I have confidence in my knowledge to provide dietary counselling to individuals with: } \\
\hline 29.6 & 43.9 & 9.4 & 16.1 & 0.9 & a) elevated LDL cholesterol & 0.9 & 6.3 & 10.3 & 70.5 & 12.1 \\
\hline 42.9 & 43.8 & 8.0 & 4.9 & 0.4 & b) impaired renal function & 4.5 & 44.2 & 27.7 & 20.5 & 3.1 \\
\hline 50.2 & 39.6 & 6.2 & 3.6 & 0.4 & c) bowel cancer & 9.8 & 43.8 & 28.6 & 17.0 & 0.9 \\
\hline 33.6 & 41.3 & 7.6 & 16.6 & 0.9 & d) type 2 diabetes & 3.6 & 12.1 & 17.9 & 60.1 & 6.3 \\
\hline 50.7 & 40.4 & 5.8 & 2.7 & 0.4 & e) chronic obstructive airways disease & 12.6 & 50.7 & 29.6 & 7.2 & 0.0 \\
\hline 40.0 & 42.7 & 7.1 & 9.3 & 0.9 & f) celiac disease & 6.7 & 33.3 & 30.7 & 25.8 & 3.6 \\
\hline
\end{tabular}

1: strongly disagree; 2 : disagree; 3 : unsure; 4 : agree; 5 : strongly agree

Table 5 - Median of the answers according to 5-point Likert scale to "Perception of competencies for dietary counselling" before and after NM $(n=225)^{1}$

\begin{tabular}{|c|c|c|c|c|}
\hline & & $\begin{array}{c}\text { Before NM } \\
\text { Median }\end{array}$ & $\begin{array}{c}\text { After NM } \\
\text { Median }\end{array}$ & $p$ value ${ }^{a}$ \\
\hline \multicolumn{2}{|c|}{ I feel able to do dietary counselling as a preventive measure of the disease. } & 2.00 & 4.00 & $<0.001^{* *}$ \\
\hline \multicolumn{2}{|c|}{ I have the necessary knowledge to provide food guidance in children up to one year old. } & 1.00 & 2.00 & $<0.001^{* *}$ \\
\hline \multicolumn{2}{|c|}{ I feel confident to give dietary counselling in the treatment of obesity. } & 2.00 & 4.00 & $<0.001^{* *}$ \\
\hline \multirow{6}{*}{$\begin{array}{l}\text { I have confidence in my knowledge to } \\
\text { provide dietary counselling to individuals } \\
\text { with: }\end{array}$} & a) elevated LDL cholesterol & 2.00 & 4.00 & $<0.001^{* *}$ \\
\hline & b) impaired renal function & 2.00 & 3.00 & $<0.001^{* *}$ \\
\hline & c) bowel cancer & 1.00 & 2.00 & $<0.001^{* *}$ \\
\hline & d) type 2 diabetes & 2.00 & 4.00 & $<0.001^{* *}$ \\
\hline & e) chronic obstructive airways disease & 1.00 & 2.00 & $<0.001^{* *}$ \\
\hline & f) celiac disease & 2.00 & 3.00 & $<0.001^{* *}$ \\
\hline
\end{tabular}

\section{a: Wilcoxon test}

$* *: p<0.001$, before versus after

in the treatment of obesity or other specific diseases with nutritional issues.

After NM classes, almost three quarters of the students felt able to provide dietary counselling as a preventive measure of disease. About $70.0 \%$ of students felt confident to provide dietary counselling in the treatment of obesity and to individuals with elevated LDL cholesterol. More than half of the students felt they had the competencies to provide dietary counselling to individuals with type 2 diabetes. However, approximately $50.0 \%$ of students still did not feel moderately or strongly confident to give dietary counselling to children up to age 1 and to individuals with the other 
Table 6 - PREDIMED's total score before and after NM by sex $(n=225)$

\begin{tabular}{lccc}
\hline & Women & Men & p value \\
& $\mathrm{M} \pm \mathrm{SD}$ & $\mathrm{M} \pm \mathrm{SD}$ & \\
\hline Before NM & $6.79 \pm 2.10$ & $6.57 \pm 1.84$ & 0.469 \\
After NM & $7.56 \pm 1.88$ & $6.85 \pm 1.90$ & $<0.05^{\star}$ \\
\hline
\end{tabular}

a: Mann-Whitney test for comparation between groups

*: $p<0.05$, after $->$ women vesus men

diseases with nutritional issues (Table 4).

Regarding the perception of competencies for dietary counselling, after NM classes there was an increase in the level of agreement according to the Likert scale in all the propositions. These differences were statistically significant $(p<0.001)$ (Table 5).

\section{PREDIMED}

The mean PREDIMED score had increased after NM classes (Wilcoxon test; $6.73 \pm 2.04$ vs $7.38 \pm 1.90 ; p<$ 0.001). However, the students presented, in both time points, a moderate adherence to MD. Women had always a higher total score compared with men (Table 6). After NM classes, only women had an increase of the mean score values $(6.79 \pm 2.10$ vs $7.56 \pm 1.88 ; p<0.001)$.

We also found that $80.9 \%$ of participants did not have a high adherence to the MD either at the beginning or at the end of the study. There were no statistically significant differences between the number of students adhering to and not adhering to the MD, before and after NM frequency (Table 7).

\section{DISCUSSION}

Our study confirms that nutrition education in the medical curriculum of the first years of training has a positive influence on the attitudes, knowledge, and confidence of medical students to provide dietary counselling.

Most medical students answered affirmatively to all questions related with good habits or eating behaviours, and the acquisition of knowledge had an impact in specific attitudes related with nutritional labels, healthy choices, and control of what to eat or to avoid unhealthy foods.

Furthermore, the proportion of affirmative answers to the questions "Do you know how to correctly interpret nutritional labels?" and "Do you avoid eating foods with high content of fat and/or sugar?" had an increase of approximately $30 \%$. Many of the students reported having improved their

Table 7 - Adherence to MD before and after NM $(n=225)$ ability to interpret food labels, as well as to avoid consumption of foods rich in fat and sugar, which can also be related with the fact that the students are now more able to identify these types of foods.

The WHO recommends the consumption of five portions of fruit/vegetables daily, regarding the question about that in the end of the semester the percentage of the students that reported reach the recommendation $(43.5 \%)$ is lower than the national reality $(47.3 \%){ }^{16}$

In the knowledge section, even though the proportion of right answers only increased significantly in three questions, the initial proportion of right answers before the classes was high. This may be the result of more awareness about the importance of nutrition by the general population that tends to be more informed, even if the most trustworthy sources are not always chosen. ${ }^{17}$

Other surveys found that physicians agree on the importance of nutrition in their medical practice but do not feel comfortable to provide dietary counselling to their patients. ${ }^{5}$ This can be changed if medical students are adequately prepared to do it. In our study, most students felt able to provide dietary counselling as a preventive measure of the disease. However, in cases of children up to age 1 or in the treatment of obesity or other specific diseases more than $50 \%$ of students reported not feeling able to do it.

The literature points out that it is important to include dietitians as members of medical faculty and this is also a recommendation made by medical students in order to improve the medical curriculum. ${ }^{3,18}$ Although this was not a specific aim of our study, the results here presented corroborate the pedagogical advantage in the involvement of dietitians in nutrition education.

The study shows an increase in the perception of competencies for dietary counselling, after NM classes, in all the situations. However, no student felt strongly confident about their competencies for dietary counselling. This can be the result of the fact that the students involved are in the first year of IMM, which is a preclinical year and thus, distant from the medical reality and from contact with patients, meaning it can be more difficult to report the self-perception of carrying out dietary counselling. ${ }^{7}$

The results show that, regardless of the moment inquired, about $81 \%$ of medical students did not have a high adherence to the MD, which has also been reported in other studies carried out in Portugal, even though it is a country that is part of the Mediterranean basin and whose food

\begin{tabular}{|c|c|c|c|c|c|}
\hline & & \multicolumn{3}{|c|}{ After NM } & \multirow[b]{2}{*}{$p$ value $^{a}$} \\
\hline & & High adherence to MD & $\begin{array}{l}\text { Low and moderate } \\
\text { adherence to MD }\end{array}$ & Total & \\
\hline \multirow{3}{*}{ 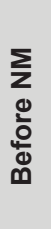 } & High adherence to MD & $\begin{array}{c}9 \\
(4.0 \%)\end{array}$ & $\begin{array}{c}12 \\
(5.3 \%)\end{array}$ & $\begin{array}{c}21 \\
(9.3 \%)\end{array}$ & \multirow{3}{*}{0.123} \\
\hline & $\begin{array}{l}\text { Low and moderate } \\
\text { adherence to MD }\end{array}$ & $\begin{array}{c}22 \\
(9.8 \%)\end{array}$ & $\begin{array}{c}182 \\
(80.9 \%)\end{array}$ & $\begin{array}{c}204 \\
(90.7 \%)\end{array}$ & \\
\hline & Total & $\begin{array}{c}31 \\
(13.8 \%)\end{array}$ & $\begin{array}{c}194 \\
(86.2 \%)\end{array}$ & $\begin{array}{c}225 \\
(100 \%)\end{array}$ & \\
\hline
\end{tabular}


heritage could be maintained. ${ }^{19}$ Contrary to what was described in literature, ${ }^{15}$ women had greater adherence to MD compared to men, with a significant difference after curricular unit frequency. This significant difference can be related to the fact that more women report making their own meals (56\% vs 50\%), and thus have greater ability to modify their dietary habits and to adhere to the MD. This result points towards the need to design an integrative approach to promote the adherence to our academic community.

Proper nutrition education for physician's results in acquisition of good attitudes and eating behaviours, increase of knowledge and importance about nutrition and perception of competencies for dietary counselling. This is likely to have a positive impact on patient care and health outcomes, which is the ultimate goal of physicians.

This inclusion in the first few years may be important so that throughout medical training students can gain greater sensitivity and be more prone to make decisions based also on data about the impact of nutrition. However, this study did not allow to verify if the increased nutritional knowledge will have impact on their future medical practice, so it is important to evaluate the same students in the clinical years or during medical practice.

\section{REFERENCES}

1. Perlstein R, McCoombe S, Shaw C, Nowson C. Medical students' perceptions regarding the importance of nutritional knowledge and their confidence in providing competent nutrition practice. Public Health. 2016;140:27-34

2. Andrade C, Ferreira B. A saúde dos portugueses 2016. Lisboa: DireçãoGeral da Sáude; 2016.

3. Hanninen S, Rashid M. Assessment of students' perception of the nutrition curriculum in a Canadian undergraduate medical education program. J Can Assoc Gastroenterol. 2019;2:141-7.

4. Womersley K, Ripullone K. Medical schools should be prioritising nutrition and lifestyle education. BMJ. 2017;359:j4861.

5. Adams KM, Kohlmeier M, Powell M, Zeisel SH. Nutrition in medicine: nutrition education for medical students and residents. Nutr Clin Pr. 2010;25:471-80.

6. Mogre V, Stevens FC, Aryee PA, Amalba A, Scherpbier AJ. Why nutrition education is inadequate in the medical curriculum: a qualitative study of students' perspectives on barriers and strategies. BMC Med Educ. 2018;18:18-26.

7. Vetter ML, Herring SJ, Sood M, Shah NR, Kalet AL. What do resident physicians know about nutrition? An evaluation of atitudes, selfperceived proficiency knowledge. J Am Coll Nutr. 2009;49:1841-50.

8. Danek RL, Berlin KL, Waite GN, Geib RW. Perceptions of nutrition education in the current medical school curriculum. Fam Med. 2017;49:803-6.

9. Adams KM, Kohlmeier M, Zeisel SH. Nutrition education in U.S. medical schools: latest update of a national survey. Acad Med. 2010;85:153742.

10. Chung M, van Buul V, Wilms E, Nellessen N, Brouns F. Nutrition education in European medical schools:results of an international

\section{CONCLUSION}

Our study showed that nutrition education in the first year of the IMM can have a positive impact in the attitudes and eating behaviours, knowledge and importance about nutrition and in the perception of competencies for dietary counselling of medical students.

\section{PROTECTION OF HUMANS AND ANIMALS}

The authors declare that the procedures were followed according to the regulations established by the Clinical Research and Ethics Committee and to the Helsinki Declaration of the World Medical Association.

\section{DATA CONFIDENTIALITY}

The authors declare having followed the protocols in use at their working center regarding patients' data publication.

\section{CONFLICTS OF INTEREST}

The authors declare they have no conflict of interest.

\section{FUNDING SOURCES}

This work had no financial support.

survey. Eur J Clin Nutr. 2014;68:844-6.

11. Broad J, Wallace M. Nutrition and public health in medical education in the UK: reflections and next steps. Public Health Nutr. 2018;31:2523-5.

12. Schlair S, Hanley K, Gillespie C, Disney L, Kalet A, Darby P, et al. How medical students ' behaviors and attitudes affect the impact of a brief curriculum on nutrition counseling. J Nutr Educ Behav. 2012;44:653-7

13. Walsh CO, Ziniel SI, Delichatsios HK, Ludwig DS. Nutrition attitudes and knowledge in medical students after completion of an integrated nutrition curriculum compared to a dedicated nutrition curriculum: a quasi-experimental study. BMC Med Educ. 2011;11:58.

14. Adams KM, Lindell KC, Kohlmeier M, Zeisel SH. Status of nutrition education in medical schools. Am J Clin Nutr. 2006;83:S941-4.

15. Martínez-González M, García-Arellano A, Toledo E, Salas-Salvadó $\mathrm{J}$, Buil-Cosiales $\mathrm{P}$, Corella D, et al. A 14-item mediterranean diet assessment tool and obesity indexes among high-risk subjects: The PREDIMED trial. PLoS One. 2012;7:e43134.

16. Lopes C, Torres D, Oliveira A, Severo M, Alarcão V, Guimar S, et al. Inquérito Alimentar Nacional de Atividade Física, 2015-2016. Porto: Universidade do Porto; 2017.

17. Probst $Y$. Dietitians in the electronic age: progressing towards e-health. Nutr Diet. 2011;68:177-8.

18. Burch E, Crowley J, Laur C, Ray S, Ball L. Dietitians' perspectives on teaching nutrition to medical students. J Am Coll Nutr. 2017;36:415-21.

19. Rodrigues S, Caraher M, Trichopoulou A, de Almeida M. Portuguese households' diet quality (adherence to Mediterranean food pattern and compliance with WHO population dietary goals): Trends, regional disparities and socioeconomic determinants. Eur J Clin Nutr. 2008;62:1263-72. 